\title{
User Requirements for an Ocean Observation Satellite System
}

\author{
William G. Pichel \\ NOAA/NESDIS, Office of Research and Applications, E/RA3, \\ Room 102 WWBG, 5200 Auth Road, Camp Springs, MD 20746 \\ Tel: (301) 763-8231 X166, Fax: (301) 763-8020, Email: William.G.Pichel@noaa.gov \\ James McGuire \\ NASA, Integrated Program Office E/IP Centre Building \\ 8455 Colesville Rd. Suite 1450, Silver Spring, MD 20910 \\ Tel: (301) 427-2121 X127, Fax: (301) 427-2164, Email: James.Mcguire@noaa.gov \\ CDR Donald Taube \\ Defense Mapping School \\ $585521^{\text {st }}$ St. Suite 101, Fort Belvoir, VA 22060-5921 \\ Tel: 703-805-2557, Fax: 703-805-5921
}

\begin{abstract}
A summary of an on-going study of a U.S. Ocean Observer Satellite System is presented. Included are the genesis and scope of the study, details of how the measurement requirements were developed, a summary of the Ocean Observer User Requirements Document, and a sketch of the notional instruments that have been proposed to meet the observational requirements .
\end{abstract}

\section{INTRODUCTION}

The Integrated Program Office (IPO) is an office composed of National Aeronautics and Space Administration (NASA), U.S. Department of Commerce (DOC) National Oceanic and Atmospheric Administration (NOAA), and U.S. Department of Defense (DoD) personnel. It was created to implement the Congressional requirement to integrate the separate U.S. civilian and military weather satellite systems into a single integrated national system. This new satellite system is called the National Polar-orbiting Operational Environmental Satellite System (NPOESS). The first of the NPOESS satellites is to be launched in approximately 2008 and is to operate for 10 years. NPOESS not only covers the operational needs of the weather community, but also to some extent the operational land community needs, and to a lesser extent the operational ocean community needs [1].

Recognizing the lack of emphasis in the NPOESS program in the observation of ocean parameters, the IPO decided to do a study (the Ocean Observer Study) to determine U.S. ocean observational needs and to determine how to implement the ocean requirements of the U.S. user community.

This paper provides an overview of the user requirements that are emerging from the Ocean Observer Study (which is still underway) and a brief summary of the proposed instrumentation. It must be emphasized that this is still just a study and that there is currently no funding to implement the recommendations of the study.

\section{THE REQUIREMENTS PROCESS}

As the first step of the Ocean Observer Study, an Ocean Observer User Requirements Document was compiled. This document was developed by an extensive User Requirements Team consisting of environmental scientists and end users in many U.S. Government (USG) agencies, academia, and private industry (see Table 1). Each group of parameters (e.g., sea surface winds, sea surface height, or sea ice) was specified by a separate team which developed and refined the requirements for that parameter or group of related parameters. Emphasis was placed on ocean parameters; however, cryospheric (e.g., Sea and Lake Ice Concentration/Age/Motion/Edge Location), hydrologic (e.g., Flood Mapping), land (e.g., Land Surface Deformation), and atmospheric (e.g., Mesoscale Atmospheric Features) parameter requirements were included if the parameter could be generated by the same technology needed to meet the ocean requirements. Early in the process, it was discovered that there was a need to emphasize coastal parameters (e.g., coastal ocean color). Every attempt was made to include all the ocean environmental parameters measurable remotely from space, now or in the next 4 to 8 years. Instrument Teams then designed various altimeters, a scatterometer, various synthetic aperture radars, and a high-resolution visible and infrared imaging spectrometer that met the requirements that were not addressed by the current NPOESS satellite system design. Finally, a Satellite Team developed a number of satellite configuration options which included the suggested instruments.

\section{OCEAN OBSERVER REQUIREMENTS SUMMARY}

The Ocean Observer User Requirements Document [2] consists of a series of Environmental Data Requirements (EDRs) grouped generally by discipline; e.g., oceanographic, 
TABLE 1

SUMMARY OF USER REQUIREMENTS TEAM COMPOSITION

\begin{tabular}{|c|c|c|c|c|c|c|c|c|}
\hline & \multicolumn{8}{|c|}{ Number of Participants } \\
\hline $\begin{array}{l}\text { Team } \\
\text { Category }\end{array}$ & $\begin{array}{l}\longleftarrow \\
\bigotimes \\
Z\end{array}$ & 峞 & คి & ס̊ & 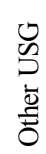 & 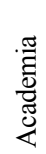 & 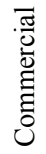 & 䒿 \\
\hline Oceans & 17 & 9 & 9 & 1 & 2 & 22 & 5 & 65 \\
\hline Cryosphere & 2 & 4 & 3 & 1 & 3 & 6 & - & 19 \\
\hline Hydrology & 1 & 2 & 3 & 1 & 5 & 3 & - & 15 \\
\hline Land & - & 1 & 3 & 2 & - & 5 & 1 & 12 \\
\hline Atmosphere & 1 & - & 1 & - & - & 5 & - & 7 \\
\hline Management & 26 & 23 & 6 & 3 & 2 & 3 & 2 & 65 \\
\hline
\end{tabular}

land, or hydrologic requirements. A typical EDR consists of a definition, a table of requirements, an explanation, and a justification The emphasis within each EDR is on what measurement is to be made, at what resolution, accuracy, and frequency. By design, there is no reference to how the observation is to be taken; thus, there are no instrumental requirements. For this paper, however, we have grouped the observational requirements by instrument in order to logically include some of the results of the instrument studies. Table 2 summarizes the EDR requirements for what we define as the basic measurement to be made from each Ocean Observer instrument. In general, the basic measurement is that EDR that most defines the instrument characteristics. Each EDR table of requirements typically contains: horizontal cell size (i.e. spatial distance between measurements), mapping uncertainty (maximum error in geographic position), measurement range (parameter range over which accuracy and precision or uncertainty must be maintained), measurement accuracy (bias) and precision (standard deviation) or uncertainty (root-mean-square error), refresh (maximum time interval between consecutive observations), long-term stability (maximum drift in bias during the mission lifetime - 15 years), timeliness (maximum time between observation and product delivery), and geographic coverage (extent of coverage on the Earth). There are two sets of requirements for each EDR: (1) minimally acceptable requirements (Threshold), and optimum requirements (Objective). In actuality, the set of primary EDRs (see Tables 3-6), not just the basic measurement, define the required instrument characteristics. Secondary EDRs shown in these tables are other environmental measurements that can be made from the instrument, but these secondary measurements can either be made more accurately with some other instrument or are not measurable as well as desired from the instrument. A summary of the EDRs for each instrument and some of the results of the instrument study are presented in the next four sections.

TABLE 2

ENVIRONMENTAL DATA REQUIREMENTS FOR THE BASIC MEASUREMENTS FOR EACH OCEAN OBSERVER PROPOSED INSTRUMENT

\begin{tabular}{|c|c|c|c|c|c|c|c|c|}
\hline \multirow{3}{*}{$\begin{array}{c}\text { Requirement } \\
\text { Basic Measurement }\end{array}$} & \multirow{2}{*}{\multicolumn{2}{|c|}{$\begin{array}{c}\text { Scatterometer } \\
\text { Global Sea Surface Wind } \\
\text { Vectors }\end{array}$}} & \multirow{2}{*}{\multicolumn{2}{|c|}{$\frac{\text { Altimeter* }}{\text { Sea Surface Height }}$}} & \multirow{2}{*}{\multicolumn{2}{|c|}{$\begin{array}{c}\text { Synthetic Aperture Radar } \\
\text { High Resolution All } \\
\text { Weather Imagery }\end{array}$}} & \multirow{2}{*}{\multicolumn{2}{|c|}{$\frac{\text { Coastal Ocean Imager }}{\text { Coastal Ocean Color }}$}} \\
\hline & & & & & & & & \\
\hline & Threshold & Objective & Threshold & Objective & Threshold & Objective & Threshold & Objective \\
\hline Horizontal Cell Size & $20 \mathrm{~km}$ & $1 \mathrm{~km}$ & $15 \mathrm{~km}$ & $15 \mathrm{~km}$ & $5-100 \mathrm{~m}$ & $1-50 \mathrm{~m}$ & $100 \mathrm{~m}$ nadir & $\begin{array}{l}100 \text { m worst } \\
\text { case }\end{array}$ \\
\hline Mapping Uncertainty & $5 \mathrm{~km}$ & $1 \mathrm{~km}$ & $\begin{array}{l}\text { Radial Orbit } \\
\text { Acc: } 3 \mathrm{~cm}\end{array}$ & $\begin{array}{l}\text { Radial Orbit } \\
\text { Acc: } 1 \mathrm{~cm}\end{array}$ & $5-100 \mathrm{~m}$ & $1-50 \mathrm{~m}$ & $100 \mathrm{~m}$ nadir & $\begin{array}{l}100 \text { m worst } \\
\text { case }\end{array}$ \\
\hline Measurement Range & $\begin{array}{c}3-35 \mathrm{~m} / \mathrm{s} \\
0-360^{0}\end{array}$ & $\begin{array}{c}1-50 \mathrm{~m} / \mathrm{s} \\
0-360^{\circ}\end{array}$ & - & - & - & - & $\begin{array}{c}0.1-10 \mathrm{~W} \\
\mathrm{~m}^{-2} \mu \mathrm{m}^{-1} \mathrm{ss}^{-1}\end{array}$ & $\begin{array}{l}0.05-10 \mathrm{~W} \\
\mathrm{~m}^{-2} \mu \mathrm{m}^{-1} \mathrm{~s}^{-1}\end{array}$ \\
\hline $\begin{array}{l}\text { Measurement } \\
\text { Accuracy/ Precision/ } \\
\text { Uncertainty }\end{array}$ & $\begin{array}{c}\text { Uncert: } \\
\text { Speed: } 2 \\
\text { m/s or } 10 \% \\
\text { Dir: } 20^{\circ} \text { to } \\
25^{\circ}\end{array}$ & $\begin{array}{c}\text { Uncert: } \\
\text { Speed: } 1 \\
\text { m/s or } 10 \% \text {, } \\
\text { Dir: } 10^{\circ}\end{array}$ & $\begin{array}{l}\text { Acc: } 3 \mathrm{~cm} \\
\text { Prec: } 3 \mathrm{~cm}\end{array}$ & $\begin{array}{l}\text { Acc: } 2 \mathrm{~cm} \\
\text { Prec: } 2 \mathrm{~cm}\end{array}$ & $\begin{array}{l}\text { Radiometric } \\
\text { Acc: } 1.5 \mathrm{~dB}\end{array}$ & $\begin{array}{l}\text { Radiometric } \\
\text { Acc: } 0.5 \mathrm{~dB}\end{array}$ & $\begin{array}{l}\text { Acc: } 2 \%, \\
\text { Prec: } 2 \%\end{array}$ & $\begin{array}{l}\text { Acc: } 1 \%, \\
\text { Prec: } 1 \%\end{array}$ \\
\hline Refresh & $6 \mathrm{hrs}$ & $2 \mathrm{hr}$ & 20 days & 20 days & $12-48 \mathrm{hr}$ & $1-24 \mathrm{hr}$ & $24 \mathrm{hr}$ & $2 \mathrm{hr}$ \\
\hline Long-term Stability & $0.5 \mathrm{~m} / \mathrm{s}$ & - & $1 \mathrm{~mm} / \mathrm{yr}$ & $1 \mathrm{~mm} / \mathrm{yr}$ & $1.0 \mathrm{~dB}$ & $1.0 \mathrm{~dB}$ & $\begin{array}{l}\text { At } 443 \mathrm{~nm}: \\
0.50 \mathrm{~W} \\
\mathrm{~m}^{-2} \mu \mathrm{m}^{-1} \mathrm{ss}^{-1}\end{array}$ & $\begin{array}{l}\text { At } 443 \mathrm{~nm}: \\
0.250 \mathrm{~W} \\
\mathrm{~m}^{-2} \mu \mathrm{m}^{-1} \mathbf{s}^{-1}\end{array}$ \\
\hline Timeliness & $90 \mathrm{~min}$ & $15 \mathrm{~min}$ & $3 \mathrm{mo}$. & $3 \mathrm{mo}$. & $2 \mathrm{hr}$ & $1 \mathrm{hr}$ & $48 \mathrm{hr}$ & $24 \mathrm{hr}$ \\
\hline $\begin{array}{l}\text { Geographic } \\
\text { Coverage }\end{array}$ & $\begin{array}{l}\text { Global Ice- } \\
\text { free Ocean }\end{array}$ & $\begin{array}{l}\text { Global Ice- } \\
\text { free Ocean }\end{array}$ & $\begin{array}{c}66 \mathrm{~S} \text { to } \\
66 \mathrm{~N} \text { lat. }\end{array}$ & $\begin{array}{c}85 \mathrm{~S} \text { to } 85 \mathrm{~N} \\
\text { lat }\end{array}$ & $30 \mathrm{~min} /$ orbit & $30 \mathrm{~min} /$ orbit & $\begin{array}{l}\text { Selected } \\
\text { Coastal } \\
\text { Regions }\end{array}$ & $\begin{array}{l}\text { Selected } \\
\text { Coastal } \\
\text { Regions }\end{array}$ \\
\hline
\end{tabular}

*Note: Altimeter specifications are for Global Scale measurements (there are Basin Scale and Mesoscale specifications as well). 


\section{A. Scatterometer}

Scatterometers send out radar pulses at different angles and by measuring the characteristics of the backscattered energy deduce wind speed and direction. The amount of energy backscattered is proportional to the amplitude of the capillary and small gravity Bragg waves on the ocean's surface, which in turn are proportional to the wind speed. Current plans for NPOESS are to use passive microwave polarimetric radiometers to measure wind speed and direction. An experimental mission called WindSat will be launched in 2002 to test this technology for wind measurement. If both wind speed and direction can be measured to the accuracy desired with passive techniques, then a scatterometer instrument will not be considered for the Ocean Observer. If, however, a scatterometer proves to be required, the notional instrument is a version of the NASA AlphaSCAT which is to be a conical scanning, dual-beam, Ku-band $(13.4 \mathrm{GHz})$ radar with a swath width of 1600 to $2400 \mathrm{~km}$ (depending on spacecraft altitude) and a spatial resolution of $20 \mathrm{~km}$. Table 3 lists the EDR's satisfied with this instrument.

\section{B. Altimeter}

Altimeters use radar pulses and accurate timekeeping to very precisely measure the distance from the Earth's surface to the satellite, and thus are capable of measuring changes in elevation of the ocean's surface to obtain sea-level change, sea level anomalies associated with phenomena such as El Niño, geostrophic current velocity, and deep-ocean bathymetric features. A number of altimeter options are under study for the Ocean Observer including a nadir altimeter (such as JASON II), a wide-swath altimeter, a delayed doppler altimeter, a cross track delayed doppler altimeter, and various combinations of more than one altimeter. Delayed doppler instruments (Ku band) are being studied to enable altimetric measurements in coastal regions. Wide Swath (up to $200 \mathrm{~km}$ ) interferometric altimeters (Ku band) improve horizontal cell size over that achievable with nadir altimeters. Table 4 lists the EDRs to be observed by the altimeter.

\section{Synthetic Aperture Radar}

Synthetic aperture radars (SARs) record amplitude and phase of the backscattered radar signal, and with sophisticated signal

TABLE 3

SCATTEROMETER ENVIRONMENTAL DATA REQUIREMENTS

\begin{tabular}{|l|}
\hline PRIMARY \\
Global Sea Surface Winds (Speed and Direction) \\
Global Sea Surface Wind Stress \\
\hline SECONDARY \\
\hline Sea and Lake Ice Concentration/Age/ Motion/ Edge Location \\
\hline
\end{tabular}

TABLE 4

\section{ALTIMETER ENVIRONMENTAL DATA REQUIREMENTS}

\begin{tabular}{|l|}
\hline PRIMARY \\
Sea Surface Height \\
Coastal Sea Surface Ht. \\
Ocean Wave Characteristics-Significant Wave Ht. \\
Open Ocean Currents \\
Mesoscale Ocean Features \\
Sea Ice Freeboard \\
\hline SECONDARY \\
\hline Sea and Lake Ice Concentration/Age/ Motion/ Edge Location \\
Bathymetry (Deep Ocean and Near Shore) \\
Snow Water Equivalent Mapping \\
\hline
\end{tabular}

processing allow production of high resolution imagery. By carefully controlling the satellite orbit so that an exact repeat orbit is achieved, repeat pass interferometry (RPI) is possible, allowing applications such as Land Surface Deformation and Glacier Volumetric Change. Two satellites in close formation enable cross track interferometry (CTI) for Land Surface Topography mapping, or along track interferometry (ATI) for measuring Littoral Currents and Surf Conditions. A single, long, electronically partitioned antenna can also be used for ATI. There are many SAR configurations being considered with differing modes and interferometric capabilities. The SAR is a large cost-driver for the Ocean Observer System, so the final choice will in large part be determined by budget realities. In general, however, the desired applications require the SAR system to be interferometric with two frequencies, C- and L-band, including some multi-polarization capability (at least $\mathrm{HH}$ and $\mathrm{VV}$ ), with a number of modes ranging from high-resolution single beam modes with resolutions as high as $5 \mathrm{~m}$ to multiple-beam ScanSAR modes with resolutions as coarse as $100 \mathrm{~m}$ and a swath width of $600 \mathrm{~km}$ (or $1200 \mathrm{~km}$ for a twosided SAR). Table 5 lists the EDRs that could be met using data from the SAR instruments under consideration.

\section{Coastal Ocean Imager}

One of the primary missions of the Ocean Observer is to adequately observe our coastal environments. It was recognized that the NPOESS moderate-resolution Visible/Infrared Imager/Radiometer Suite (i.e. the VIIRS) will not have sufficient ocean color or SST resolution to adequately observe our nation's smaller estuaries, bays, straits and rivers. Applications in these regions include coastal dynamics (modeling), human health (water quality, red tide warnings, pollution), oil spill response, aquaculture, and fisheries management. These applications require coincident ocean color and SST measurements. Table 6 lists the EDRs that were identified for what has been termed the "Coastal Ocean Imager" which is envisioned to be an imaging spectrometer with a resolution of 100 meters and a swath width of 100 to $150 \mathrm{~km}$. The Navy's National EarthMap Observer (NEMO) instrument is the prototype for this spectrometer. The current design shows $64,10 \mathrm{~nm}$ wide 
TABLE 5

SYNTHETIC APERTURE RADAR ENVIRONMENTAL DATA REQUIREMENTS

\begin{tabular}{|l|}
\hline PRIMARY \\
\hline High Resolution All Weather Imagery \\
Coastal Sea Surface Winds and Wind Stress \\
Ocean Wave Characteristics--Ocean Wave \\
Direction/Wavelength \\
Oil Spill Location \\
Vessel Positions \\
Littoral Currents \\
Surf Conditions \\
Mesoscale Ocean Features \\
Sea and Lake Ice Concentration/Age/Motion/Edge Location \\
Ice of Land Origin (Icebergs) \\
River Ice Location/Condition \\
Glacier Volumetric Change \\
Continental Ice Sheet Melt Zone \\
Ice-Sheet Motion \\
Ice Sheet Grounding Line Position \\
Flood Mapping \\
Snow Water Equivalent Mapping \\
Regional Soil Moisture \\
Land Surface Topography and Deformation \\
Land Surface Freeze/Thaw State \\
Vegetation Classification/Biomass \\
Mesoscale/Microscale Atmospheric Features \\
\hline SECONDARY \\
Ocean Wave Characteristics - Significant Wave Ht. \\
Bathymetry (Deep Ocean and Near Shore) \\
Open Ocean and Surface Currents \\
Soil Moisture (Surface) \\
\hline
\end{tabular}

TABLE 6

COASTAL OCEAN IMAGER ENVIRONMENTAL DATA REQUIREMENTS

\begin{tabular}{|l|}
\hline PRIMARY \\
Coastal Imagery \\
Coastal Ocean Color \\
Coastal Chlorophyll \\
Coastal Ocean Optical Properties \\
Coastal Sea Surface Temperature \\
Ocean Mesoscale Features \\
Ice Surface Temperature \\
Coastal Wetland Mapping \\
\hline SECONDARY \\
Sea and Lake Ice Concentration/Age/Motion/Edge Location \\
Vegetation Classification/ Biomass \\
Coastal Change Detection \\
\hline
\end{tabular}

visible and near IR bands in the range of 0.38 to 1.0 micrometers plus two bands for SST calculation at 11 and 12 micrometers. The instrument would be programmed to change its angle of view either continuously or in frequent steps in order to follow the coastline of interest.

\section{CONCLUSIONS}

As the result of the input of scientists and managers in many government agencies, universities, and private companies, a User Requirements Document (URD) for an ocean observing satellite system has been developed. Although focussing on ocean parameters measurable by remote sensing techniques, the document also covers cryospheric, land, hydrologic, and atmospheric parameters if they are derivable from the instrumentation needed to provide the ocean measurements. Environmental Data Requirements were developed for each parameter and documented in the URD. The URD has provided input to the Ocean Observer Study Instrument and Satellite Teams which have developed notional instruments for scatterometer, altimeter, synthetic aperture radar, and visible/infrared spectrometer measurements, and a number of proposed satellite configurations.

\section{ACKNOWLEDGMENTS}

Funding for the Ocean Observer Study came from the DOC/DoD Integrated Program Office (IPO). The requirements came from the IPO Joint Agency Requirements Group and from many of the members of the User Requirements Team. The authors would like to thank the Team members for their essential input and for their many reviews of the User Requirements Document.

\section{REFERENCES}

[1] Joint Agency Requirements Group, Integrated Program Office, 2001, Integrated Operational Requirements Document II, $149 \mathrm{pp}$.

[2] Ocean Observer Study Team, Integrated Program Office, 2001, Ocean Observer User Requirements Document, NOAA, draft document, $93 \mathrm{pp}$. 